М. І. Марущак, І. Я. Криницька, Н. В. Петренко, Г. Г. Габор ДВНЗ “Тернопільський державний медичний університет імені

I. Я. Горбачевського МОЗ Украӥни”

\title{
ВИКЛАДАННЯ В МЕДИЧНОМУ УНІВЕРСИТЕТІ НА ЗАСАДАХ ЛІДЕРСТВА
}

\author{
M. I. Marushchak, I. Ya. Krynytska, N. V. Petrenko, H. H. Habor \\ I. Horbachevsky Ternopil State Medical University \section{LEADERSHIP} \\ TEACHING AT THE MEDICAL UNIVERSITY ON THE BASIS OF
}

\begin{abstract}
Мета роботи - проаналізувати особливості викладання в медичному університеті на засадах лідерства.
Основна частина. В еру глобалізації, інтернаціоналізації, розвитку інформаційних технологій відбувається перехід від поверхневого підходу (surface approach) викладання до глибинного (deер approach). Викладання на засадах лідерства спрямоване на розкриття потенціалу кожного, активно залучаючи студентів в освітній процес, надихаючи їх на запитання і пошук відповідей на них. Студент отримує знання через аналіз та синтез інформації, інтегруючи їх із загальними здібностями комунікації, критичного мислення та вирішення проблем, а викладач лише допомагає в цьому.

Висновки. Розвиток теорії дистрибутивного лідерства передбачає лідерство усіх співробітників навчального закладу, незалежно від посади, яку вони обіймають, та рівня відповідальності, здійснення впливу на колег, а також на загальний напрям розвитку вишу.

Викладач-лідер - це професіонал зі збереженими професійними цінностями і чітко визначеною сферою діяльності. Викладання на засадах лідерства спрямоване на розкриття потенціалу кожного студента та активне їх залучення в освітній процес.
\end{abstract}

Ключові слова: викладання; лідерство; сфера діяльності; професійні цінності.

The aim of the work - to analyze the peculiarities of teaching in the medical university on the basis of leadership.

The main body. In the era of globalization, internationalization, the development of information technology is the transition from the surface approach to deep approach. Teaching on a leadership basis aims at uncovering everyone's potential, actively engaging students in the educational process, inspiring them to ask questions and searching answers to them. A student acquires knowledge through analysis and synthesis of information, integrating them with general communication abilities, critical thinking and problem solving, and the teacher only helps with this.

Conclusions. The development of the theory of distributive leadership implies the leadership of all employees of the educational institution, regardless of the position they occupy and the level of responsibility, the impact on colleagues, as well as on the general direction of higher education.

The teacher-leader is a professional with retained professional values and a well-defined sphere of activity. Teaching based on leadership aims at uncovering the potential of each student and actively engaging them in the educational process.

Key words: teaching; leadership; areas of activities; professional values.

Вступ. На сучасному етапі багато процесів, які стосуються управління організаціями та лідерства, постійно видозмінюються, що пов’язане, насамперед, із збільшенням ступеня свободи працівників. Ефективність роботи будь-якого закладу вищої освіти (ЗВО) залежить від командної роботи, тому ознаки лідерства тепер орієнтуються не на ієрархічне підкорення та посилення контролю, а на принципи командності і розвиток довіри. На даному етапі керівники та лідери не можуть ефек-

(c) М. I. Марущак, I. Я. Криницька, Н. В. Петренко, Г. Г. Габор тивно управляти тільки за рахунок прийняття рішень і розповсюдження наказів, а змушені зацікавити співробітників щодо успішного виконання завдань [1]. В міру збільшення ступеня свободи працівників викладач розглядається як повноцінна одиниця університетської спільноти, яка не тільки надихається, але й спонукає до дій для досягнення спільної мети.

Усвідомлення того, що ідеального лідера не буває, привело до розвитку теорії дистрибутивного лідерства, яка грунтується на понятті колегіальності та 
завоювала популярність останніми десятиліттями в університетській освіті як альтернатива традиційним моделям лідерства. Вона передбачає лідерство усіх співробітників 3ВО, незалежно від посади, яку вони обіймають, та рівня відповідальності, здійснення впливу на колег, а також на загальний напрям розвитку вишу. Пропонується більш інклюзивний погляд на організаційну життєдіяльність 3ВО, де працівники та команди на всіх рівнях 3 ВО колективно впливають на стратегічний напрям його розвитку за допомогою лідерства [2].

Мета роботи - проаналізувати особливості викладання в медичному університеті на засадах лідерства.

Основна частина. Насамперед, необхідно чітко визначити основні поняття “викладання” і “лідерство”.

Викладання (Teaching) - спеціально організована цілеспрямована діяльність викладача з підготовки та постачання під час навчального заняття освітньої (педагогічної) інформації, якою він володіє актуально чи потенційно, з метою забезпечення навченості споживачів цієї інформації [3].

Лідерство в закладах вищої освіти - це здійснення спрямованого, але не директивного впливу на працівників, мета якого полягає у спонуканні їх до діяльності переважно творчого, інноваційного характеру для досягнення певних організаційних цілей, яке базується на владі і повноваженнях (авторитеті), наданих лідеру його послідовниками.

В еру глобалізації, інтернаціоналізації, розвитку інформаційних технологій відбувається перехід від поверхневого підходу (surface approach) викладання до глибинного (deep approach) [4]. Розглянемо основні відмінності цих двох підходів для того, щоб їх зрозуміти.

Поверхневий підхід передбачає велику кількість матеріалу у програмі, при цьому студент отримує часткові знання від переданої викладачем інформації, докладаючи мінімальних зусиль для отримання позитивної оцінки його знань, додаткові знання із дисципліни студенту не цікаві, зворотний зв'язок щодо прогресу навчання слабкий. Такий підхід викладачі ЗВО використовували довший час, частково застосовуючи його і зараз. Відсутність автономії у навчанні змушує викладача працювати відповідно до методичних рекомендацій, роль викладача носить функцію передавача знань. Вільям Артур Ворд писав: “ЗВичайний викладач - розповідає. Хороший викладач - пояснює. Найкращий викладач показує. Викладач-лідер - надихає”. Застосування глибинного підходу дає змогу студентам формувати нові ідеї, переосмислювати давно відоме шляхом запитань, дискусій, обговорень, презентацій, доповідей, повідомлень, що потребує від викладача майстерності та відповідних здібностей. У нашому університеті ми відходимо від поверхневого підходу до навчання та щораз частіше використовуємо глибинний підхід. Для цього створений симуляційний центр, щоб студент міг практично відпрацювати навички, а не перечитувати десятки описових сторінок; кафедри забезпечені великою кількістю обладнання, наприклад, на кафедрі функціональної і лабораторної діагностики студенти не обмежуються теорією, а практично навчаються на електрокардіографі, спірографі, електроенцефалографі. Практично орієнтований підхід до навчання, особливо в медичних навчальних закладах, надає студентам відчуття задоволення від навчання та глибокого розуміння дисципліни.

Яке ж воно викладання на засадах лідерства? Таке викладання спрямоване на розкриття потенціалу кожного, активно залучаючи студентів в освітній процес, надихаючи їх на запитання і пошук відповідей на них. Студент отримує знання через аналіз та синтез інформації, інтегруючи їх із загальними здібностями комунікації, критичного мислення та вирішення проблем, а викладач лише допомагає в цьому. Все частіше до освітнього процесу застосовують поняття “міждисциплінарні зв’язки” зв’язки, які дають можливість пов’язати в систему всі знання, набуті з різних дисциплін, а також набуті нові знання на основі цих зв’язків, що є надзвичайно актуальним [5].

Хто ж він - викладач-лідер? Чесна і надійна людина, яка живе тим, що робить; якій довіряє студент; яка вміє слухати, аналізувати, адекватно реагувати на зміни, робити висновки і визнавати помилки. Викладач-лідер має високу компетентність у сфері своєї професійної діяльності, чіткі світоглядні позиції, широкий кругозір та ерудицію, професійну, правову і психологічну культуру, що забезпечить повагу студентів та колег-викладачів і його високий особистий авторитет у них. Чи є такі серед нас? Слід відмітити, що в нашому навчальному закладі відбулися динамічні зміни в найвищому керівництві від “єдино правильної думки” до “я дослухаюся до кожного, адже ефективність роботи залежить від кожного з нас”. Серед професорськовикладацького складу викладання на засадах лідерства в нашому університеті здійснюється лише на окремих кафедрах, де створюється тісний контакт між викладачем і студентами, включаючи події, 
до яких залучені і викладачі, і студенти. Необхідно пам’ятати, що викладати на засадах лідерства може тільки справжній викладач-лідер.

Відповідно до “The UK Professional Standards Framework for teaching and supporting learning in higher education” (рамка професійних стандартів для викладання та підтримки навчання у вищій освіті Великої Британії), виділяють три виміри профілю сучасного викладача-лідера, такі, як: сфера діяльності, основні знання, професійні цінності [6].

До сфери діяльності (Areas of Activities) викладача належать: розроблення і планування освітньої діяльності та освітньої програми; викладання та підтримка навчання; оцінка знань студентів та зворотний зв'язок із ними; розвиток ефективного освітнього середовища, підходів до викладання та підтримки студентів; постійний професійний розвиток, дослідження з проблем викладання та оцінювання професійних практик.

До основних знань (Core Knowledge) викладача відносять: знання дисципліни, яка викладається; відповідні методи викладання, навчання та оці- нювання; використання відповідних технологій навчання; методи оцінювання ефективності викладання; забезпечення якості викладання.

До професійних цінностей (Professional Values) викладача відносять такі, як: повага до кожного студента; заклик до участі у вищій освіті та до рівних можливостей студентів; використання фактичних даних результатів досліджень з викладання та постійного професійного розвитку викладача; розуміння контексту вищої освіти, застосування професійної практики [7].

Висновки. Розвиток теорії дистрибутивного лідерства передбачає лідерство усіх співробітників навчального закладу, незалежно від посади, яку вони обіймають, та рівня відповідальності, здійснення впливу на колег, а також на загальний напрям розвитку вишу.

Викладач-лідер - це професіонал зі збереженими професійними цінностями і чітко визначеною сферою діяльності. Викладання на засадах лідерства спрямоване на розкриття потенціалу кожного студента та активне їх залучення в освітній процес.

5. Сура Н. А. Міждисциплінарність навчання: нові завдання в умовах модернізації вищої професійної іншомовної освіти / Н. А. Сура // Духовність особистості: методологія, теорія і практика. - 2014. - Вип. 3 (62). С. $156-164$.

6. The UK Professional Standards Framework for teaching and supporting learning in higher education, 2011. - Retrieved from https://www.heacademy.ac.uk/about/news/ higher-education-sector-celebrates-teaching-excellence.

7. Оптимальні шляхи та моделі розвитку інституційного потенціалу університетів в контексті глобального лідерства : методичні рекомендації / [О. Боднарук, I. Драч, С. Калашнікова та ін.]. - К. : ТОВ “Видавничий дім “Плеяди”, 2017. - 100 с.

of educational programs. Guidelines]. Kyiv: DP “NVTs "Priorytety" [in Ukrainian].

4. Leadership foundation for higher education. Stimulus paper by Paul Ramsden. Leadership for better student experience. What do senior executives need to know. (2013). ihed.org.ua Retrieved from: http://ihed.org.ua/images/ biblioteka/conf_Elite-III_05.2017_ELITE.Education-forLeadership_VOU_II-2017-170p.pdf

5. Sura, N.A. (2014). Mizhdystsyplinarnist navchannia: novi zavdannia $\mathrm{v}$ umovakh modernizatsii vyshchoi profesiinoi inshomovnoi osvity [Interdisciplinary learning: 
New challenges in modernization of higher professional secondary education]. Dukhovnist osobystosti: metodolohiia, teoriia i praktyka - Personality Spirituality: Methodology, Theory and Practice, 3 (62), 156-164 [in Ukrainian].

6. The UK Professional Standards Framework for teaching and supporting learning in higher education. (2011). www. heacademy.ac.uk. Retrieved from: https://www.heacademy. ac.uk/about/news/higher-education-sector-celebratesteaching-excellence
7. Bondaruk, O., Drach, I., Kalashnikova, S., Kovalenko, O., Kurbatov, S., Nevmerzhytska, N., Palamarchuk, O., ... Chervona, L. (2017). Optymalni shliakhy ta modeli rozvytku instytutsiinoho potentsialu universytetiv $v$ konteksti hlobalnoho liderstva: metodychni rekomendatsii [Optimal ways and models of institutional capacity development of universities in the context of global leadership: methodological recommendations]. Kyiv: TOV "Vydavnychyi dim "Pleiady” [in Ukrainian].

Отримано 03.11.17

Електронна адреса для листування: maria.marushchak21@gmail.com 